\title{
NEW SPECIES OF ACARINE FAUNA (ACARINA: MESOSTIGMATA) FROM SHEVROY RANGE OF EASTERN GHATS OF TAMIL NADU, INDIA
}

\author{
C. Chinniah and M. Mohanasundaram
}

Department of Agricultural Entomology, Tamil Nadu Agricultural University, Coimbatore, Tamil Nadu 641003, India.

\begin{abstract}
A study was conducted on the biodiversity of predatory acarines of Shevroy Range of Eastern Ghat Biosphere of Tamil Nadu. The study revealed the occurance of many new species of predatory acarine fauna, which includes three new species under the family Phytoseiidae and one from the family Cunaxidae inhabiting different flora. All these species viz., Amblyseius camarae sp. nov., Phytoseius punicae sp. nov., P. strobilanthae sp. nov. and Cunaxa eupatoriae sp. nov. have been described with illustrations in this paper.
\end{abstract}

Keywords

Acarina, Cunaxidae, Phytoseiidae, predators, key, new descriptions

$\begin{array}{lr}\text { Cm - Chelicera of male } & \text { Abbreviations } \\ \text { DF - Dorsal view of female } & \text { Cf - Chelicera of female } \\ \text { LI - LIII - Legs 1 to } 3 & \text { LIV - Leg IV } \\ \text { Mp - Meta podal plate } & \text { Pp - Peritremal plate } \\ \text { Sp - Spermatheca } & \text { TNAU - Tamil Nadu Agricultural University } \\ \text { VASf - Ventri Anal Shield of female } & \text { VASm - Ventri Anal Shield of male } \\ \text { Vf - Ventral view of female } & \text { Vm - Ventrum of male }\end{array}$

\section{Introduction}

Predacious mites of the family Phytoseiidae and Cunaxidae have been recognized as most valuable groups of predators on plant feeding mites since the middle of this century (Chant, 1959). Even mass multiplication methods have been developed to use these predators in commercial scale on a variety of crops against a range of phytophagous mites (Lo et al., 1979; Krishnamoorthy, 1982). Some of the indigenous species have been identified and reared in laboratory by very simple methods (Krishnamoorthy, 1990). More than two hundred species have been described under predatory families from different agroecological conditions in India (Gupta, 1985) only about four species have been described under Paraphytoseius and around 25 species have been recorded under the genus Phytoseius, 16 species under the family Cunaxidae from India (Gupta, 1985). Keys are provided for all these published species by Gupta, 1986. However, the reports on occurrence of new species are scanty from peninsular
India. Hence a systematic survey was undertaken to study the occurrence of native species of predatory mites from tropical forest ecosystems of Tamil Nadu and Kerala including the Shevroy Hills Range (Yercaud) under Eastern Ghat Biosphere Reserve of Tamil Nadu. The study revealed a rich diversity of acarine fauna from the different flora available in this region.

\section{Description about the study location}

Shevroy hill is a part of Eastern ghat range, situated about 30 kms from Salem City at an altitude of about 4500 feet above mean sea level. It attracts lot of visitors from India and abroad as it has a typical sub tropical climate and a cool weather. The maximum temperature rarely reaches $30^{\circ} \mathrm{C}$ during the hottest period of the year. It has diversified wild fauna especially Gaur, deer, wild boar etc., and flora (Eucalyptus, teak and other hardwood trees of timber value). Despite a large area is being cultivated with spice crops viz., pepper, cinnamom, large spice, 


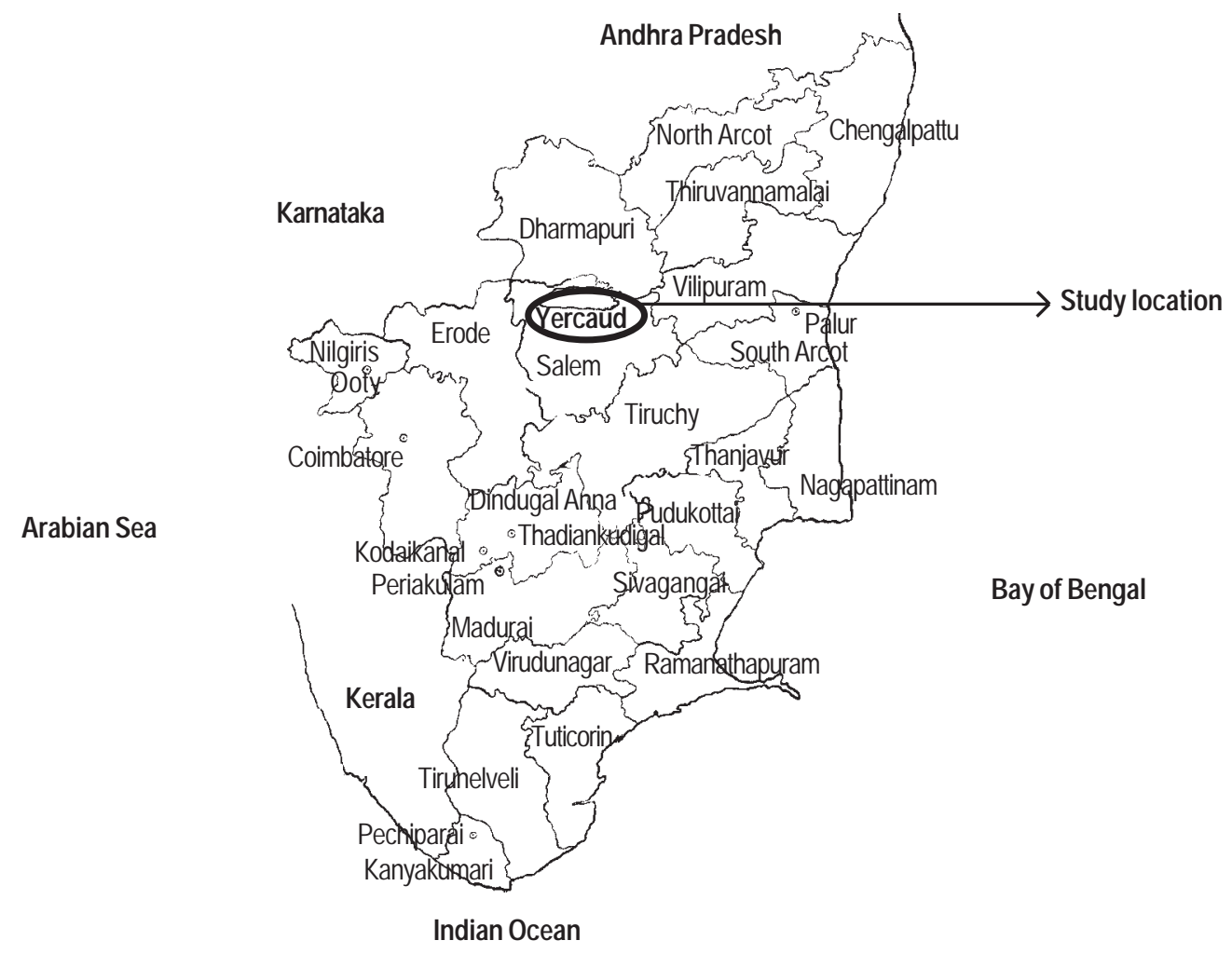

Figure 1. Map showing study site in Tamil Nadu

ginger, cardamom, mandarin and jack are the major fruit crops grown in Shevroy range. There are some Reserve Forests also, which are very sparsely inhabited by the native tribal population who chiefly collect the honey and resins from many plants. The ground vegetation includes many sub tropical weeds, which include ferns, thorny bushes etc., which incidentally harbours diversified micro Arthropods including the acarina of predatory habit.

\section{Materials and methods}

To collect the predatory mites, frequent visits were under taken to different study locations in the forest area. Bigger sized and brilliantly coloured mites were collected directly form the foliage using a handlens and a camel hairbrush and preserved in ethyl alcohol until permanent slides were prepared. Otherwise leaves, twigs and barks were collected from different plants (wild and cultivated) in clean polythene bags and examined under zoom microscope to collect the mites and prepare their permanent slides in Hoyer's medium. The specimens were thoroughly examined for chaetotaxy on dorsum, ventrum and legs, sigillotaxy, poroidotaxy gnathosomal characters etc., to fix the proper taxonomic identity with the help of available literature.

All measurements are given in microns. All the type slides have been deposited in the acarological collections maintained at the
Department of Entomology, TNAU, Coimbatore.

\section{Amblyseius (Paraphytoseius) camarae sp. nov.}

(Fig. 2-7)

Materials examined

Holotype: Female, 16.viii.1992, Yercaud (Horticultural Research Station - TNAU), Tamil Nadu, India, ex. Lantana camara L. Coll. C. Chinniah (No. 39/1) marked on slide.

Paratype: Several slides with 10 females and six males, collection detail same as holotype.

\section{Etymology}

This new species is named after the host plant Lantana camara from which it was collected.

\section{Diagnosis}

Female: Dorsal shield is smooth, elongate, incised at the level of s4, 270 long, 146 wide with 13 pairs of setae. The seate j1,j3, s4, Z5 and Z4 are long, thick and serrate measuring 34, 90, 128, 96 and 74 respectively. Other setae are small measuring between $4-$ 6 long. Two pairs of sublateral setae which are thick and serrate present on lateral integument measuring r3 48 and R1 34. Sternal shield not clear as it is very weakly sclerotized, with three pairs 
of sternal setae (30) and the $4^{\text {th }}$ pair of setae (30) lie on separate metapodal plates. Genital shield 78 wide with a pair of prominent setae. The shape of ventrianal shield as figured (Fig. 2), measuring 96 long, 50 wide with three pairs of preanal setae (20). Fourth pair of setae present on the membrane around the ventrianal shield, JV5 78 long, thick and serrate. Metapodal platelets not clear. The fixed digit of chela multidentate, movable digit bidentate (Fig. 4), the shape of spermatheca as illustrated with short cervix (Fig. 3). Peritreme extends anteriorly upto j3. Macrosetae present on leg IV: genu 26, tibia 36, basitarsus 44 and distitarsus 34. A stout errect seta present on the anterior margin of femur IV (20) besides a stout and blunt seta on genu II. The chaetotactic formula of legs: genu II, 2 2/2 2/0 1; tibia II, 1 2/1 1/1 1; genu III, 1 2/1 1/1 1; tibia III, 1 2/1 1/1 1 .

Male: The dorsal chaetotaxy similar to that of female. The shape of spermatophoral process as illustrated (Fig. 5). The measurements of macrosetae on leg IV: genu 18, tibia 26, basitarsus 34 and distitarsus 20 .

\section{Remarks}

The new species resembles Amblyseius (Paraphytoseius) multidentatus Swirski and Schechter (1961) in dorsal chaetotaxy, structure of ventrianal shield, but it can be clearly differentiated by the following characters:

- The measurements of dorsal shield and dorsal setae are varying, sternal sheild being very weakly sclerotized.

- The structure of spermatheca is quite different with short cervix. - Variation in leg chaltotaxy.

The predatory mites were found feeding on Eriophyid mites occurring along with thrips population.

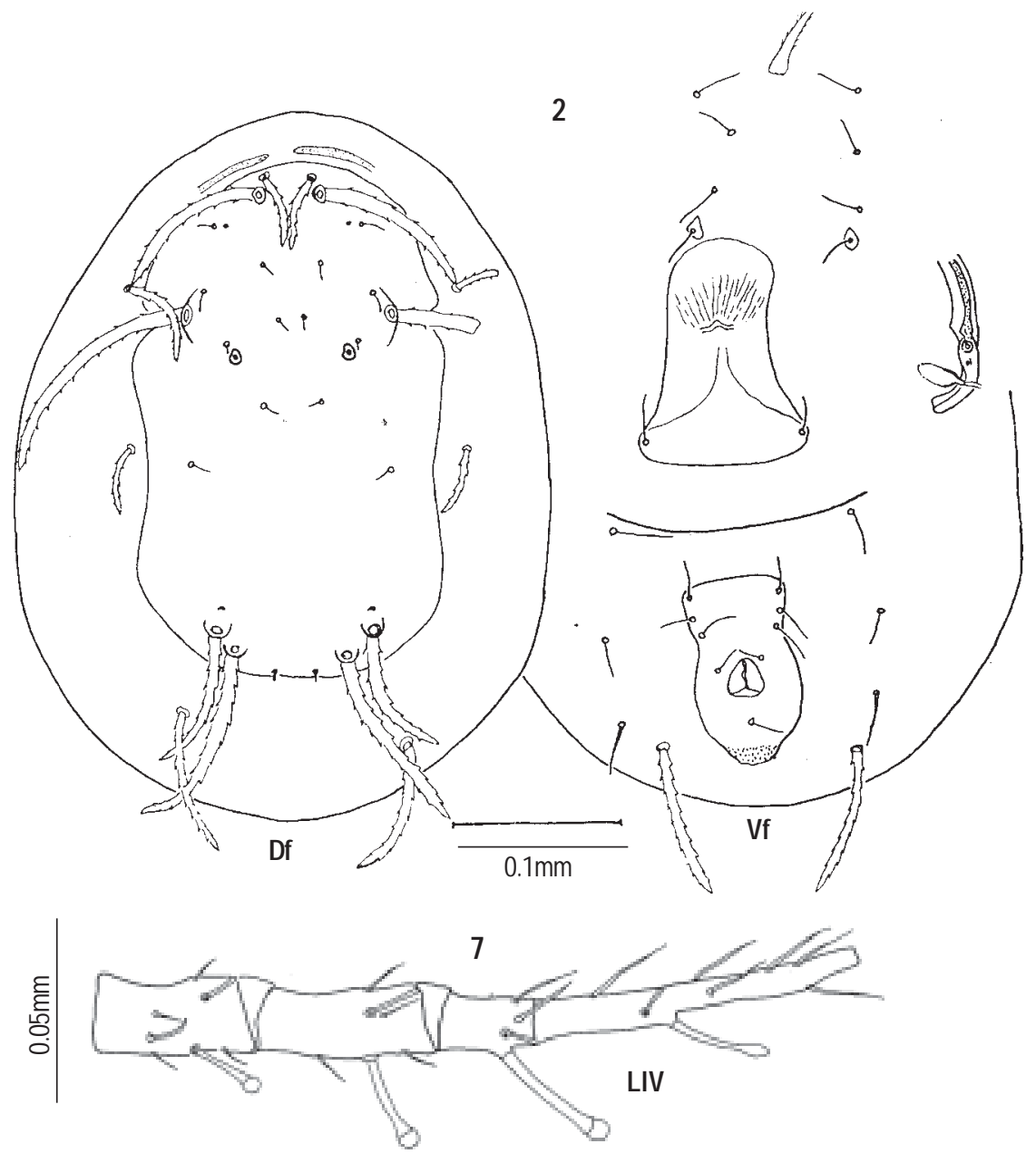

3

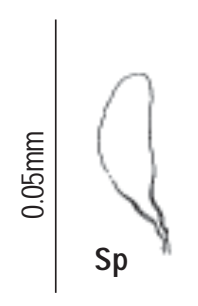

5

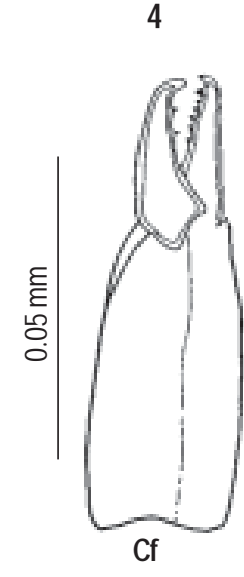

Figures 2-7. Amblyseius (Paraphytoseius) camerae sp. nov. 2 - Dorsal and ventral view (female); 3 - Spermatheca; 4 - Chelicera (female); 5 - Chelicera (male); 6 - Ventri anal shield (male); 7 - Leg IV 


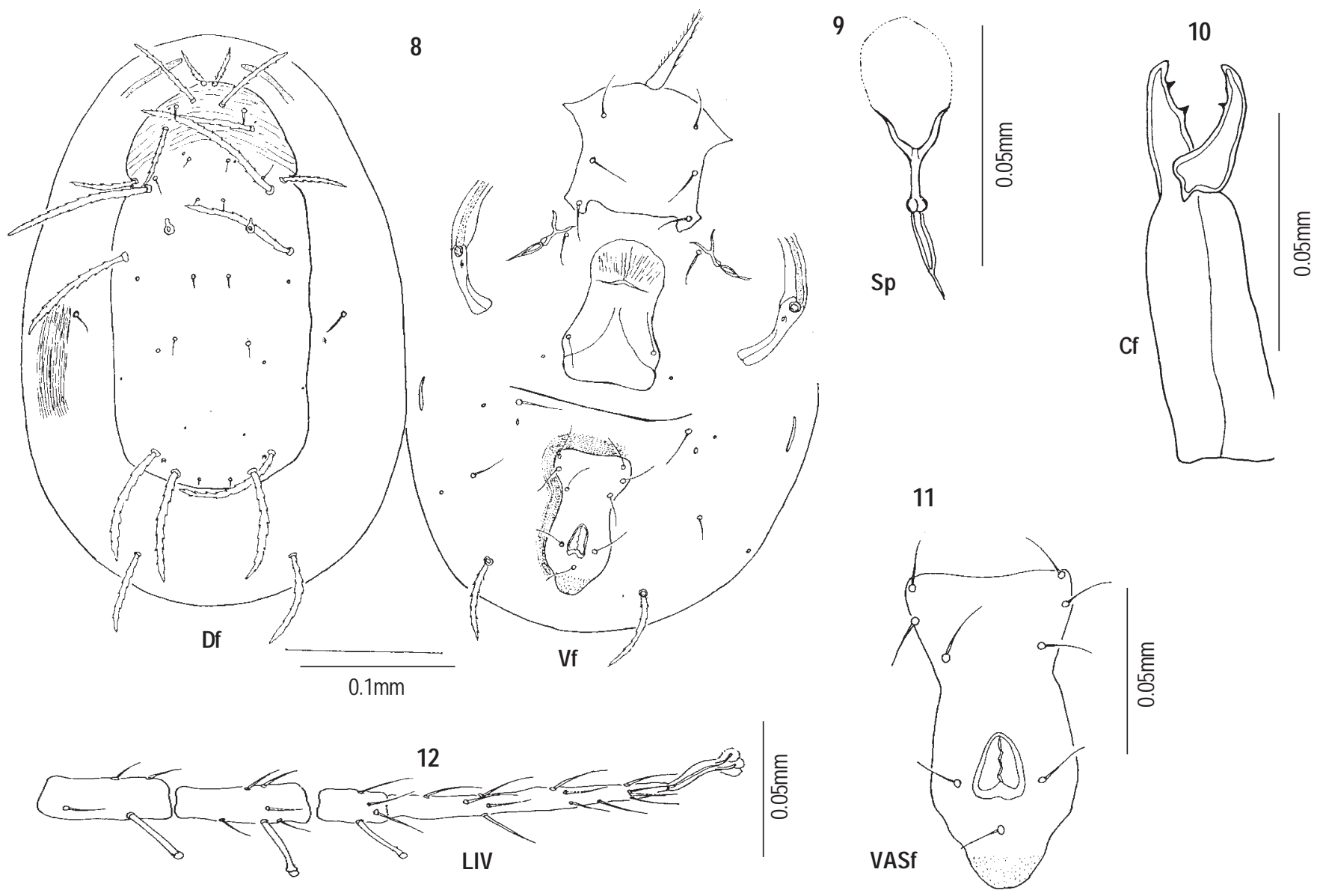

Figures 8-12. Phytoseius (Pennaseius) punicae sp. nov.

8 - Dorsal and ventral view (female); 9 - Spermatheca; 10- Chelicera (female); 11 - Ventri anal shield (female); 12 - Leg IV

\section{Phytoseius (Pennaseius) punicae sp. nov.}

(Figs. 8-12)

\section{Materials examined}

Holotype: Female, 18.vii.1993, Yercaud (Horticultural Research Station), Tamil Nadu, India, ex. Pomegranate - Punica granatum. Coll. Karuppuchamy (No. 222/4).

Paratype: Four, slides with several females on the habitats mentioned below from different localities of Tamil Nadu surveyed.

\section{Distribution}

Tamil Nadu: Yercaud, Salem, Bhavani Sagar, Erode, Nilgiris, Anaikatti Reserve Forests, Coimbatore.

Kerala: Munar.

\section{Habitat}

Coffee, Solanum torvum, Pomegranate, and an undetermined plant from Anaikatti.

\section{Etymology}

The nomenclature of this new species is based on the name of the host Punica granatum from which it was collected.

\section{Diagnosis}

Female: Dorsal shield smooth (Fig. 8), very narrow compared to the body size, 256-284 long, 124-128 wide, moderately sclerotized with 16 pairs of setae and five pairs of pores. A distinct notch present on the lateral margin of dorsal shield at the level of $\mathrm{r} 3$. A pair of proscutal solenostomes are also present on the proscutum. Setae j1, j3, z3, s4, s6, Z5, Z4, r3 are long, thick and serrate. Other setae are smooth and small. Among the two pairs of sublateral setae $\mathrm{r} 3$ present on the dorsal shield and R1 present on the lateral membrane which is also sclerotized, broad with fine striations around the dorsal shield. The measurements of various dorsal setae are j1 24-30; j3 70; z3 50-54; s4 102-110, s6 90; s5 8688, z4 84-86; r3 46-50; R1 18-20. Other setae measures between 6-10. The sternal shield (Fig. 8) faintly seen 80 long, 70 wide (longer than the width) with three pairs of setae (30), 4th pair 
present on the membrane, metasternal plates not distinct. The genital shield 80 long, 60 wide with a pair of prominent setae (24). The genital and ventrianal shield 36 apart with a thin membranous folding and fine striations in the interspace. The ventrianal shield 100 long (Fig. 11), 50 wide, the lateral margins deeply concave with three pairs of preanal setae, preanal pores absent. Three pairs of ventrianal shield, JV5 long (60-64), thick and serrate. A pair of metapodal plates present, 20 long. Chelicera 100 long, the fixed chela with 2 strong teeth, movable chela unidentate, pilus dentilus not visible. The peritreme extends anteriorly upto the base of ji. Spermatheca as illustrated (Fig. 9). The macrosetae present on leg IV (Fig. 12), genu 26, tibia 32, basitarsus 24 and distitarsus 28, all with spatulate head. The chaetotactic formula of legs. genu II, 2 2/2 0/0 1; tibia II, $12 / 11 / 11$; genu III, 1 1/2 0/1 1; tibia III, 1 1/2 1/1 1 .

Male: Unknown.

\section{Remarks}

This new species resembles Phytoseius (Pennaseius) kapuri Gupta (1969) in dorsal chaetotaxy, length of dorsal shield, shape of ventrianal shield, presence of macrosetae on leg IV etc. But the new species can be differentiated by the following characters: - The width of dorsal shield is very narrow in proportion to the entire body size in all specimens collected.

- All dorsal setae are longer in new species especially the dorsocentrals are twice longer in new species compared to $P$. kapuri; the lateral integument is more broader in new species. The post lateral angulation is prominent, the length of ventrianal shield is more (100) in new species compared to P. kapuri (7592). The setae JV5 is longer (60-64) in new species (45-60 in $P$. kapuri). The fixed chela bidentate, mobile chela unidentate where as tridentate and bidentate respectively in P. kapuri. The structure of spermatheca also varies between these two species. Apart from this, the leg chaetotactic formula clearly differentiates the new species from $P$. kapuri.

The predatory mites were feeding on various phytophagous mites actively.

\section{Phytoseius (Phytoseius) strobilanthae sp. nov.}

(Figs. 13-20)

\section{Materials examined}

Holotype: Female, marked on slide with several females, 9.xii.1992, Yercaud (Horticultural Research Station), Tamil Nadu, India, ex. Kurinchi, Strobilanthus cunthianus (Acanthaceae) Coll. P.C. Sundara Babu (No.171/3).

Paratypes: Several with 10 females and four males; collection detail same as type (No.171/1,2,4 and 5).

\section{Etymology}

The nomenclature of this new species is after the name of the host plant.

\section{Diagnosis}

Female: Body oval shaped (Fig. 13), dorsal shield, 276-280 long, 152-160 wide, rugose, strongly sclerotized with 15 pairs of setae and 2 pairs of large pores. The setae z2, j4, z5, z4, J5 are small (4) and peritreme runs anteriorly upto ji. the chelicera 86 long, fixed chela tridentate with prominent pilus dentilis, movable chela unidentate, macrosetae present on leg IV: genu nil, tibia 48-50, basitarsus 34, distitiarsus 22-24, (blunt setae) the first two setae spatulate with membraneous tip. The chaetotactic formula of legs:

genu II, 2 2/2 0/0 1; tibia II, 1 1/2 1/1 1; genu III, 1 2/2 1/0; tibia III, 1 1/1 1/1 1 .

Male: Dorsal chaetotaxy similar to female. The spermatophoral process as figured (Fig. 20). The measurements of macrosetae on leg IV: tibia 26, basitarsus 16 and distitarsus 22.

\section{Remarks}

This new species resembles Phytoseius (Phytoseius) roseus Gupta (1982) in dorsal chaetotaxy, shape of ventrianal shield, fixed digit being tridentate, presence of bulbuous macrosetae only on tibia and basitarsus of leg IV etc. But the new species can be differentiated from it by the following characters:

- Dorsal shield is broader, all the dorsal setae are longer in new species.

- The structure of spermatheca clearly differentiates the new species from other described species.

- The measurements of macrosetae on leg IV is longer in new species compared to $P$. roseus.

The predatory mites were found in large numbers on leaves, flower buds and stem along with tetranychids, oribatids and thrips.

\section{Phytoseius (Phytoseius) intermedius Evans et al., 1961} (Figs. 21-25)

\section{Materials examined}

Type: Female on slide, 18.vii.1993. Yercaud (Horticultural Research Station - TNAU), Tamil Nadu, India, ex. Pomegranate, Punica granatum, Coll. D. Karupuchamy (No. 222/6).

\section{Diagonosis}

Female: Dorsal shield 280 long, 152 wide, rugose, with 15 pairs of setae and 2-3 pairs of pores. Excepting j4, j6, j5, z5 which are short and simple all other setae are long, thick and serrate. The measurements of setae: j1 26; j3 80; z3 30; z4 26; s4 34; s6 12; z5 62 ; z4 66; sternal shield not distinct, but marked by 3 pairs of 

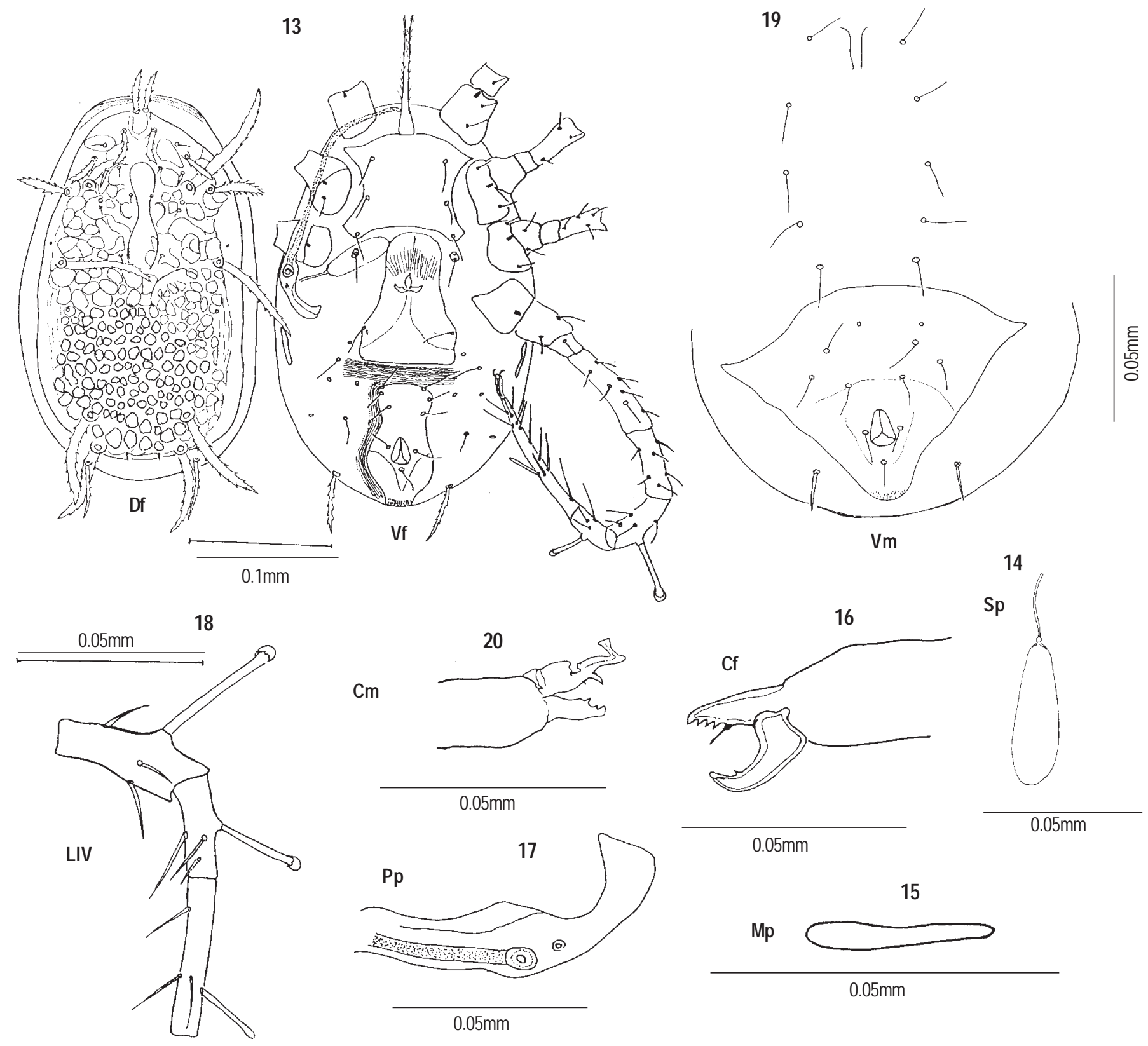

Figures 13-20. Phytoseius (Phytoseius ) strobilanthae sp. nov.

13- Dorsal and ventral view (female); 14 - Spermatheca; 15- Metapodal Plate; 16 - Chelicera (female); 17 - Pereitremal plate; 18 Leg IV; 19 - Ventrum (male); 20 - Chelicera (male)

sternal setae (24). The fourth pair of sternal setae present on the membrane as presternal plates are absent. Genital shield 66 wide, with a pair of setae (22). The genital and ventrianal shield 12 apart with a thin folding and fine striations in the interspace. The ventrianal shield 80 long, 50 wide, the laterial margins concave (Fig. 21), with 3 pairs of preanal setae, preanal pores absent. Three pairs of ventrolateral setae present on the membrane. JV5 30 long, thick and serrate. A pair of thin metapodal platelets present, 20 long. Spermatheca as figured (Fig. 22). The peritreme extends anteriorly upto j1. The chelicera 76 long, the fixed chela with 3 teeth, movable chela unidendate; pilus dentilis not clear. Macrosetae absent on legs (Fig. 25). The chaetotactic formula of legs: genu II, 1 2/0 2/0 1; tibia II, 1 1/1 2/1 1; 

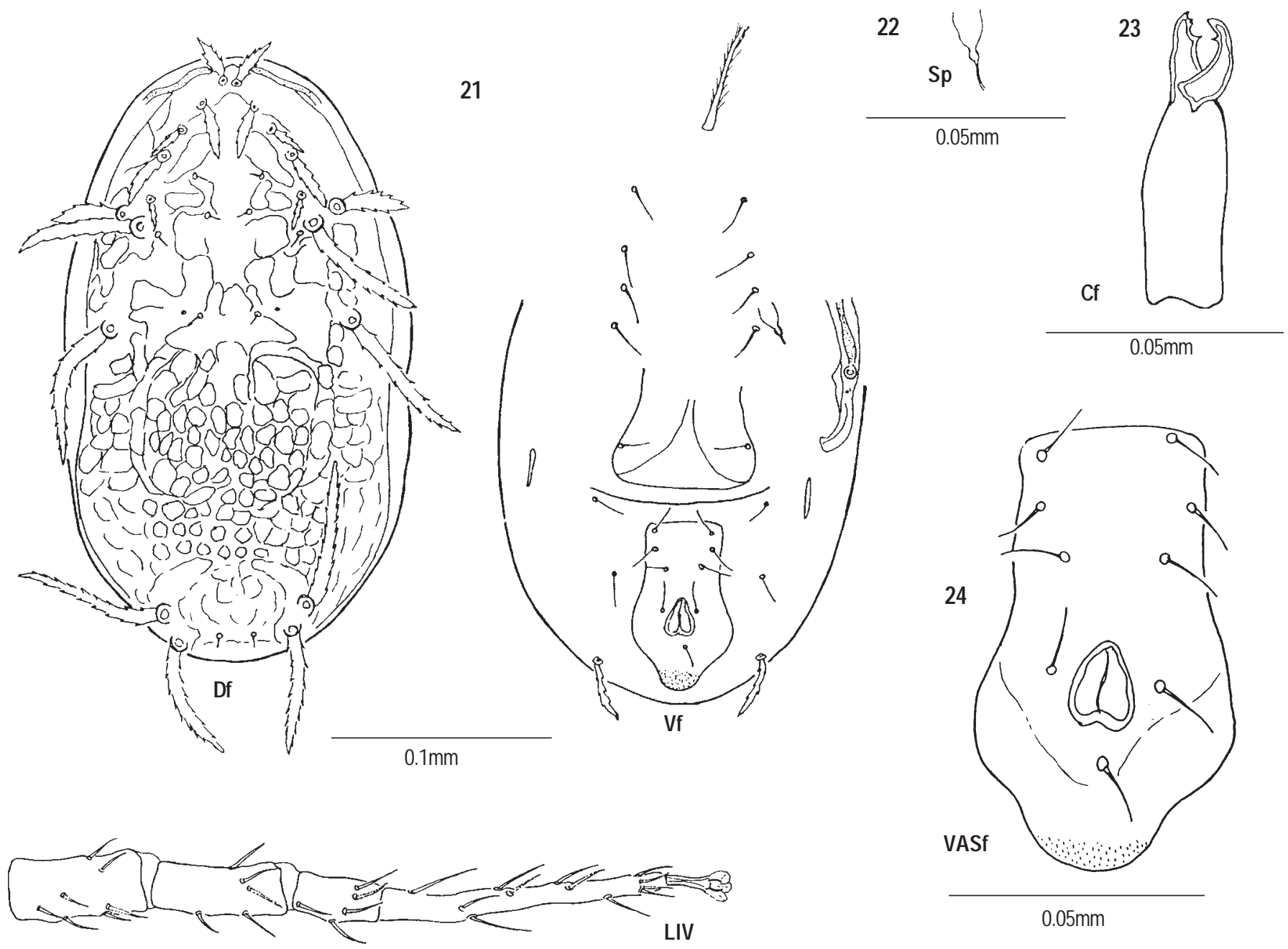

25

$0.05 \mathrm{~mm}$

Figures 21-25. Phytoseius (Phytoseius ) intermedius Evans et al., 1961

21 - Dorsal and ventral view (female); 22 - Spermatheca; 23 - Chelicera (female); 24 - Ventri anal shield (female); 25 - Leg IV

genu III, 1 2/0 2/0 1; tibia III, 1 1/1 2/1 1;

Male: Unknown.

\section{Remarks}

This specimens collected from Yercaud resembles Phytoseius (Phytoseius) intermedius Evans et al. (1961) in dorsal chaetotaxy, shape of ventrianal shield, absence of macrosetae on legs, chaetotaxy and structure of spermatheca etc. Hence by all probalility the specimens might be Phytoseius intermedius.

\section{Cunaxa eupatoriae sp. nov.}

(Figs. 26-31)

\section{Materials examined}

Holotype: Female, 25.ix.1992, Walayar Forest, Tamil Nadu, India, ex. Eupatorium sp. (Compositae), Coll. C. Chinniah (No. 105/2), Paratype: One female, on tea leaves from Yercaud (Horticultural Research Station, TNAU) (No. 220/1), marked on slide.

\section{Etymology}

This new species is named after the host plant. 


\section{Diagnosis}

Female: Body 550 long (including gnathosoma), 290 wide.

Dorsum: Gnathosoma - Hypostome subrectangular, cone shaped distally (Fig. 26). Propodosoma with a weakly sclerotized subrectangular shield originating behind the base of gnathosoma, extending to anterior region of hysterosoma. The propodosomal shield marked with broken striae. The shield with anterior sensillae (250 long) and posterior sensillae (290), both setose; two pairs of propodosomal setae $\mathrm{P} 1$ and $\mathrm{P} 2$ are also present, P1 (10) 1/4 the length of P2 (40). Hysterosoma separated from propodosoma by broken track like striae and without a definite shield. Hysterosoma complemented with setae L1, D1-D5. Setae L1, D2, D3, D4 about equal in length (46), other setae D1 50 long and D5 52 long, all setae are simple.
Venter (Fig. 27): Gnathosoma - palpi five segmented, length is about 200. Chaetotaxy of palpus as follows; trochanter none; basifemur with one slender dorso medial simple seta; telofemur with one dorsomedial finger like apophysis and dorso medial simple seta; genu inner surface with a spine like seta, medially a stout simple seta; outer surface with a slender simple seta; tibiotarsus inner surface with one long simple seta and spine like seta; anteriorly outer surface with a long simple seta; inner surface with one dorsolateral simple seta; terminating with one simple seta and small claw. Idiosomal striations small and broken. Coxae I-II contiguous, connected by small lateral apodemes, coxae III-IV contiguous, broader than coxae I-II; coxae I-IV setal formula 3-2-3-1. Hysterosoma venter with six pairs of simple setae between coxae II and distal part of the body in addition to genital and anal region. Leg IV longer than legs I-III, tarsi I-IV

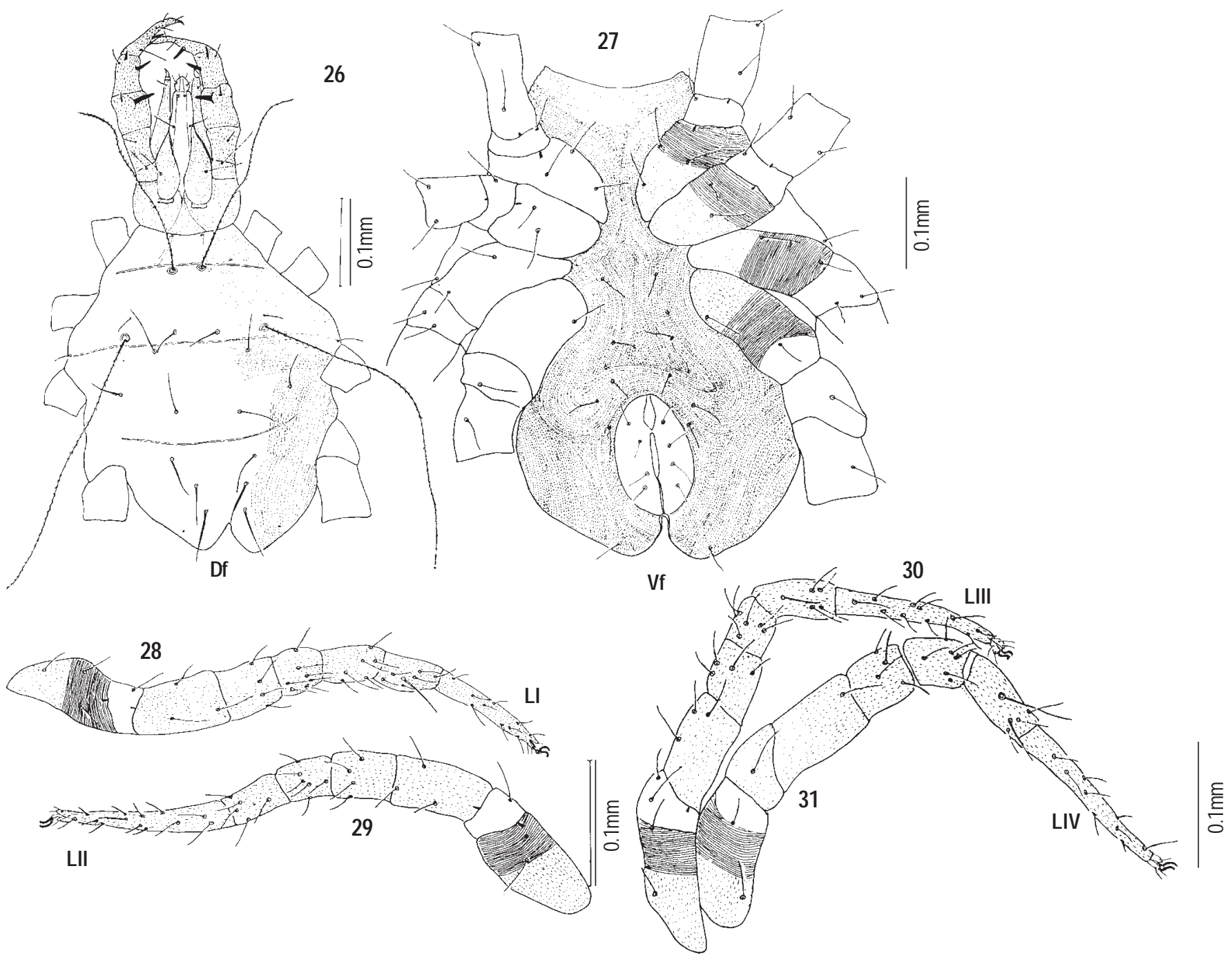

Figures 26-31. Cunaxa eupatoriae sp. nov.

26 - Dorsal view (female); 27 - Ventral view (female); 28 - Leg I; 29 - Leg II; 30 - Leg III; 31 - Leg IV 
gradually tapering excluding coxae. Chaetotaxy of legs I-IV as follows (Figs. 28-31):

trochanters, 1-1-2-1; basi femora, 3-3-3-1;

telofemora, 4-4-4-4;

genu I, 4 attenuate solenidia plus 4;

genu II, 2 attenuate solenidia plus 5;

genu III, 1 attenuate solenidion plus 5;

genu IV, 1 attenuate solenidion plus 5;

tibia I, one attenuate solenidion plus 5;

tibia II, one attenuate solenidion plus 4;

tibia III, one attenuate solenidion plus 4;

tibia IV, 1 smooth trichobothrium plus 4;

tarsus I, 7 attenuate solenidia plus 22;

tarsus II, one attenuate solenidion plus 17 ;

tarsus IV, 15.

Genital plate with four pairs of subequal simple setae.

Male: Not known.

\section{Remarks}

This new species resembles Cunaxa metzi Smiley (1992) in possessing finger like apophysis on telofemur and presence of spine like seta one each of the inner surface of genu and tibiotarsus, propodosomal shield marked by broken striae. But it is distinguished by the following characters:

- The body is quite longer and wider, the length of palpi is also longer, the finger like apophysis present medially on telofemur in new species, whereas it is present on the inner surface in C.metzi. - Presence of a stout simple seta medially on genu in new species, whereas long smooth setae present medially on genu in C.metzi. - Setae P1 1/4 the length of P2 in new species whereas it is $1 / 2$ in C. metzi.

- Setae L1 is the shortest and D1 longer than L1, D1-D3.

- Reticulation is absent on propodosomal shield, P1 being 1/4 of the $\mathrm{P} 2$ in relative length on hysterosomal shield.

\section{References}

Chant, D.A. (1959). Phytoseiid mites (Acarina: Phytoseiidae) Part I. Bionomics of seven species in southern England. Part II. A taxonomic review of the phytoseiidaae with description of 38 new species. Canadian Entomology 91(Suppl. 12): 1-166.

Evans, G., J.G. Sheals and Mcfarlane (1961). The terrestrial acari of British Isles. British Museum (Natural History) 219 pp.

Gupta, S.K. (1969). Three new species of the genus Phytoseius (Acarina; Phytoseiidae) frm India. Israel Journal of Agricultural Research 19(3): 115-120.

Gupta, S.K. (1982). On a collection of Phytoseiidae (Acarina: Mesostigmata) from Madhya Pradesh and Uttar Pradesh with descriptions of a new species of Phytoseius ribaqa. Rec. Zoological Survey of India. 79: 367-371.

Gupta, S.K. (1985). Hand book: Plant mites of India. Zoological Survey of India. Calcutta. $520 \mathrm{pp}$.

Gupta, S.K. (1986). Fauna of India-phytoseiidae (Acari: Mesostigmata. Zoological Survey of India, Calcutta 350 pp.
Krishnamoorthy, A. (1982). Mass rearing technique for an indigenous predatory mite Amblyseius tetranychivorous Gupta. (Acarina: Phytoseiidae) in the laboratory. Entomon 7: 47-49.

Krishnamoorthy, A. (1990). A self watering device used in phytoseiid rearing programme. Acarology Newsletter 17\&18: 28-29.

Lo, K.C., C.C. Ho and S.T. Chen (1979). Artificial propagation of Amblyseius taiwanicus and its toleranc of some pesticides. Journal of Agricultural Research, China 28: 251-259.

Smiley, R.L. (1992). The Predatory mite of the family Cunaxidae (Acari) of the world with a new classification. Indira Publishing House, Michigan, USA $356 \mathrm{pp}$.

Swirski, E. and R. Shechter (1961). Some phytoselid mites (Acarina: phytoseiidae) of Hong-Kong with a description of a new genus and seven new species. Israel Journal of Agricultural Research 11(2): 97-117.

\section{Key to the species of subgenus Paraphytoseius}

1. z2 and z4 serrate scleroticus

1A. $\mathrm{z} 2$ and $\mathrm{z} 4$ smooth 2

2. Spermatheca oval shaped multidentatus

2A. Spermatheca elongate. camarae sp. nov.

\section{Key to the species of subgenus Pennaseius}

1. Fixed chela bidentate, mobile chela unidentate kapuri

1A. Fixed chela tridentate, mobile chela bidentate punicae sp. nov.

\section{Key to the species of subgenus Phytoseius}

1. Ventrianal shield two times as long as broad, macro setae on leg IV are much shorker ... roseus

1A. Ventrianal shield is slightly longer than broad ....... 2 2. Macrosetae on leg IV is much longer strobilanthae sp. nov.

\section{Key to the species of Cunaxidae}

1. The finger like Apophysis present on the inner surface of telofemur Cunaxa metzi

1A. The finger like Apophysis present medially on telofemur Cunaxa eupatoria sp. nov. 